\title{
Giles Land-a mystery for S.A. Andrée and other early Arctic explorers
}

\author{
Björn Lantz \\ Technology Management and Economics, Chalmers University of Technology, Gothenburg, Sweden
}

\begin{abstract}
After the initial discovery of Giles Land (Kvitøya, Svalbard) by Cornelis Giles in 1707, it was most likely never seen by anyone again until 1876. During this lengthy period, Giles Land evolved into an enigma as various explorers and cartographers came to very different conclusions about its probable location, character or even existence. In 1897, when the engineer Salomon August Andrée tried to return over the ice after his failed attempt to reach the North Pole in a balloon, he passed through an area approximately $160 \mathrm{~km}$ north of Kvitøya where Giles Land was indicated on his map. Andrée searched for it, but there was no land in sight. The main reason why Giles Land was erroneously positioned too far north was a conjecture by a German cartographer August Petermann in 1872. While there was some distrust of Petermann's conjecture at the time, many also believed it. The erroneous understanding that Giles Land was located far north of Kvitøya was only finally dismissed in the 1930s. This article examines how this misunderstanding regarding the identity and location of Giles Land could arise and become entrenched.
\end{abstract}

\author{
Keywords \\ Kvitøya; Andrée expedition; \\ Arctic exploration; Svalbard; maps \\ Correspondence \\ Björn Lantz, Technology Management \\ and Economics, Chalmers University of \\ Technology, 41296 Gothenburg, Sweden. \\ E-mail: bjorn.lantz@chalmers.se

\section{Supplementary material} \\ To access the supplementary material, \\ please visit the article landing page.
}

\section{Introduction}

During his attempted return journey from his failed attempt to reach the North Pole, after an emergency landing in his balloon on Arctic pack ice at 82 ${ }^{\circ} 56^{\prime} \mathrm{N} 29^{\circ} 52^{\prime} \mathrm{E}$, the Swedish engineer Salomon August Andrée passed near $81^{\circ} 30^{\prime} \mathrm{N} 35^{\circ} \mathrm{E}$ in mid-August 1897. According to his recovered diary (Andrée et al. 1931), he searched many times for Giles Land through his binoculars during those days, but could not see anything but ice. Andrée was puzzled because there should have been land at that position according to his up-to-date map (Bartholomew 1897). For example, on 12 August 1897, he wrote in his diary: "we are now so near Gillis Land that we might well expect to catch a glimpse of it. But neither that nor any other land is visible" (Andrée et al. 1931: 375). How could this apparent anomaly be explained?

A closer investigation reveals that a land area, or an island, called Giles Land had been historically positioned or implied on maps at varying positions east and northeast of Svalbard. Kvitøya, an island approximately $100 \mathrm{~km}$ east of Svalbard and just north of $80^{\circ} \mathrm{N}$, which the Dutch captain Cornelis Giles discovered in 1707 and named after himself as Giles Land, was basically impossible to reach for almost 170 years after its initial discovery. Over time, Giles Land evolved to become an enigmatic legend whose position or even existence was debated among geographers and cartographers as well as among sailors and explorers. Several different islands were wrongly assumed to be Giles Land at some point during this period, and theoretically based assumptions about its location were advanced. Finally, it came to be commonly assumed that Giles Land lay approximately 160 km north of Kvitøya, just as Andrée's map indicated since, when Norwegian skipper Johan Kjeldsen "discovered" an island in 1876 that he named Kvitøya, few people understood that it was actually the same land that Giles had already discovered in 1707.

Andrée reached Kvitøya in early October 1897, but he and his two companions died there of unclear causes within a few days. The existence of a Giles Land where Andrée had searched for it a month and a half earlier would not have saved him (Lantz 2018), but the very fact that there was a widespread belief in Giles Land at the time requires an explanation. This article aims to provide a concise investigation concerning how the Giles Land mystery developed, mainly based on analyses of original maps and other relevant original sources. As is revealed, 
the person primarily responsible for the misunderstandings concerning Giles Land was the influential German cartographer August Petermann, but many other cartographers and geographers of the time also shared some responsibility for accepting Petermann's unsubstantiated claim about Giles Land. As A.M. Brice (1896: 550) put it in a discussion about Giles Land at the time when the Andrée expedition began: "It is true that you will find it in your maps to-day a degree and a half further north, but that seems to be mainly due to the waywardness of a German geographer and the complaisance of those English cartographers who believe in maps made in Germany."

\section{The historical context}

The early exploration of the Svalbard Archipelago during the 17th century, after its first documented discovery by Willem Barents in 1596, is excellently described by Conway (1906). It was mainly whaling, mostly operated by English and Dutch companies, that drove the process. The Gulf Stream kept the western and the north-western part of Svalbard relatively ice-free. The actual exploration during this initial period was mainly conducted to find new areas for whaling, but cartographers successively introduced the reported new discoveries in their maps. For example, the northernmost part of Svalbard, Sjuøyane (the Seven Islands Archipelago), was first marked on a map by Doncker (1663), who also marked the eastern limits of Spitsbergen, Barentsøya and Edgeøya. However, neither the positioning of Sjuøyane nor the characteristics of the eastern part of Svalbard were correctly displayed in Doncker's or any other early cartographer's works.

The first serious attempt for scientific exploration in the area north of Svalbard was probably made by the expedition led by C.J. Phipps in 1773. With the explicit aim "to explore how far navigation was practicable towards the North Pole" (1774: vi), Phipps reached the Seven Islands, where the largest island now bears his name, but was then forced back by the ice. The ice conditions northeast and east of Svalbard were generally very difficult; hence, few ships tried to reach these waters. Therefore, not many observations were made in the area during the 17 th, 18th and most of the 19th centuries.

\section{The mystification of Giles Land}

Kvitøya is a large island, $700 \mathrm{~km}^{2}$ in size, located at $80^{\circ} 09^{\prime} \mathrm{N} 32^{\circ} 35^{\prime} \mathrm{E}$, between Svalbard and Franz Josef Land, and arguably one of the most desolate places in the world. The name Kvitøya ("white island" in Norwegian) refers to the thick ice cap that covers almost the entire island and which reflects a strong white light when there is sunshine in the area. It was first sighted by the Dutch whaling captain Cornelis Giles in 1707, during a summer in which apparently there was relatively little ice in the Arctic seas. He proudly named the new land he had discovered after himself.

Giles' own documentation of this event in 1707 unfortunately no longer exists (Conway 1906). The earliest documented available source with details of Giles' discovery appears to be a letter dated 3 January 1775, written by John Walig, master of a Greenland ship during several decades in the 18th century, and reproduced in its entirety by D. Barrington (1818). Walig, who himself had many years of experience sailing the icy seas north of Svalbard, wrote:

But in the year 1707, Captain Cornelius [sic] Gillis [sic], having gone without any ice far to the Northward of $81^{\circ}$, sailed to the North of the Seven Islands, proceeded from thence East, and afterward Southeast, remaining to the East of the Northeast Land, when coming again to latitude $80^{\circ}$ he discovered about twenty-five miles East from the country to the Northeast very high lands, on which, as far as we know, nobody has ever been. (1818: 110-111)

Even though Giles was apparently unable to approach the land area and make a full survey, probably because he was blocked by ice, there can be no doubt that his discovery in 1707 was Kvitøya, as his description fits it very well. When looking to the north-east from a point 25 miles east of Nordaustlandet at latitude $80^{\circ}$, where Giles allegedly was, the only thing that can be seen apart from the sea is the high, shining ice cap of Kvitøyjøkulen that covers almost the entire island. In fact, it is possible to see Kvitøya all the way from Nordaustlandet when the weather is clear, so it is quite feasible that Giles only saw it from some distance in 1707.

It should also be noted that the spelling of the name applied to the land area was "Commandeur Giles Land" on the map of the Svalbard Archipelago that Gerard van Keulen created in approximately 1714, based on data from Giles himself and fellow Dutchman Outger Rep, where the western edge of Kvitøya is implied at its actual position (van Keulen 1969-1970 [ca. 1714]). Different spellings exist on later maps and documents, such as "Gillies," "Gilies" or "Gillis," but "Giles" is the best authenticated form. Moreover, van Keulen explicitly marked the land area on his map as "ontdekt 1707, is hoog Land" ("discovered 1707, is high land"; Fig. 1).

The location of Giles Land continued to appear approximately at its correct position on later maps during the 18th century. For example, the French cartographer and map publisher Georges-Louis Le Rouge made a map of the Svalbard Archipelago in 1744, on which Giles Land was marked "Terre de Gilles découverte en 


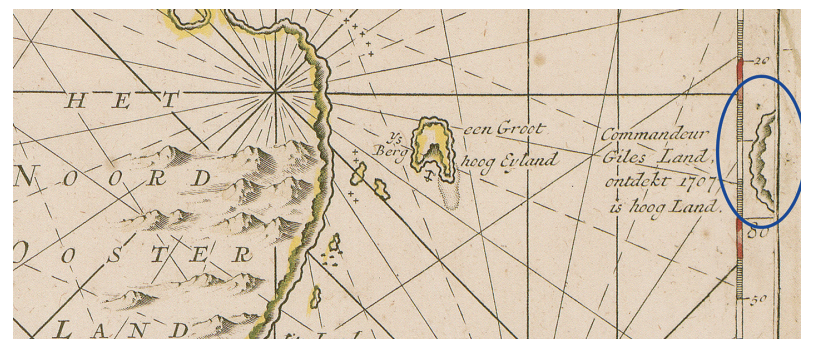

Fig. 1 Detail of van Keulen's map (1714) with "Commandeur Giles Land" circled. See the supplementary file for more information about, and larger versions of, the maps referred to in this article.

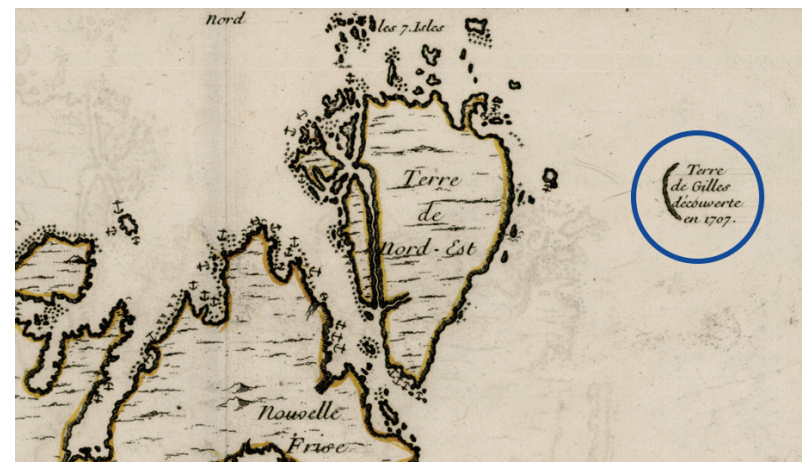

Fig. 2 Detail of Le Rouge's map (1744) with “Terre de Gilles" circled.

1707" ("Gilles Land, discovered in 1707"; Le Rouge 1758; Fig. 2). Another such example is the Svalbard map (Bellin 1780 [1758]), made in 1758 by Jacques Nicolas Bellin, hydrographer and engineer in the French Navy, on which Giles Land was marked as "Pais devé découvert par le Capt Gilles en 1707" ("Land discovered by Capt Gilles in 1707"; Fig. 3). The cartographers at that time appear to have simply relied on van Keulen's previous map.

Because the seas to the east of Svalbard generally had and have much more pack ice than the seas to the north and, in particular, to the west of Svalbard (because of the Gulf Stream), there was almost no human activity recorded there during the 18th and 19th centuries, especially from $79^{\circ} \mathrm{N}$ and above. Hence, Giles' discovery was not confirmed for a long time. Instead, newly discovered, and in some cases imagined, islands at other positions east of Svalbard were reported as "Giles Land" and inscribed on some later maps. For example, the explorer Adolf Erik Nordenskiöld, best known for being the first to complete the North-east Passage in 1878-1880 in the steamship Vega, published a map (Fig. 4) in relation to his 1863-1864 Swedish expedition to the area (Dunér $\&$ Nordenskiöld 1865) on which a large island is located at approximately $79^{\circ} \mathrm{N} 26^{\circ} \mathrm{E}$, based on observations from the top of the mountain Kvitberget just north of Barentsøya.

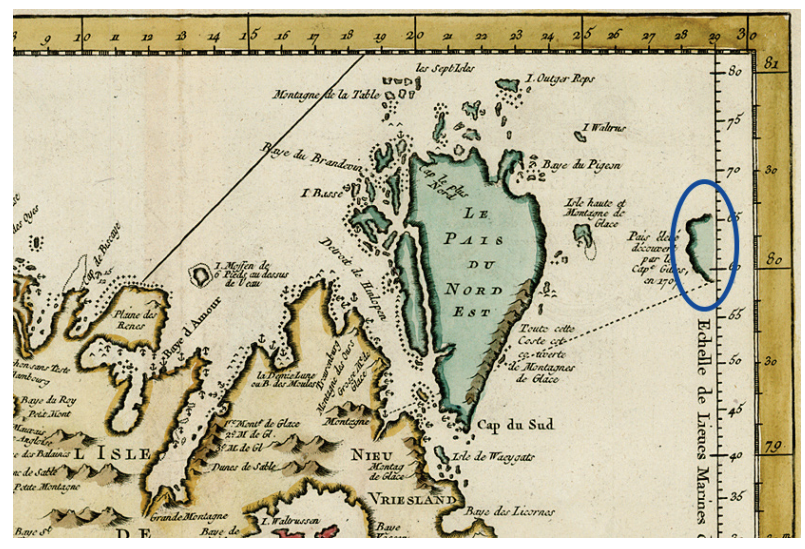

Fig. 3 Detail of Bellin's map (1758) with "Land discovered by Capt Gilles in 1707" circled.

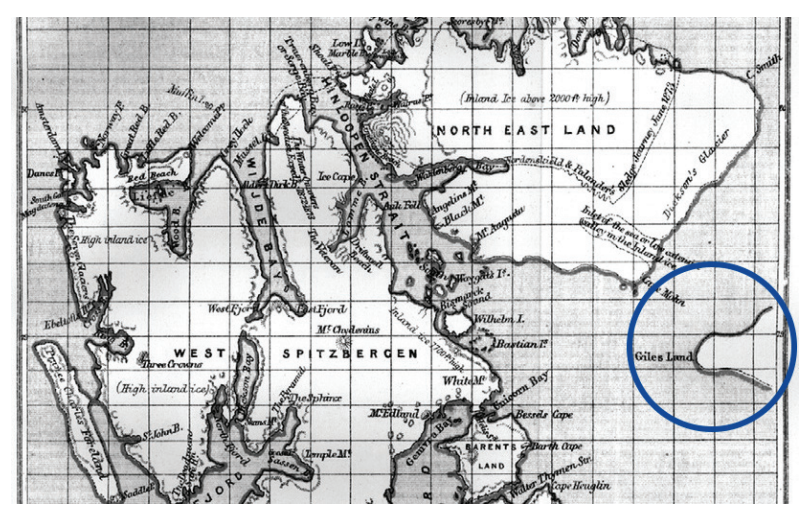

Fig. 4 Detail of Nordenskiöld's map (1865) with “Giles Land” circled.

In his book on this expedition (Dunér et al. 1867), Nordenskiöld states with confidence that he had been able to see the westernmost part of Giles Land. What Nordenskiöld saw, however, was not Giles Land, but rather Svenskøya, the westernmost island in the Kong Karls Land island group, whose discovery itself was surrounded by considerable controversy during the 1860s and 1870s (Wråkberg 2015). For some reason, Nordenskiöld did not seem to take into account that the land he saw was a long way south-east of the position where Giles Land was located on van Keulen's original map. Later, Nordenskiöld claimed that the reason why he had declared the land he had seen from the top of Kvitberget to be Giles Land was to "avoid loading the map unnecessarily with new names" (Leslie 1879).

During the 1850s and 1860s, several sightings of land at different locations east and south-east of Svalbard were reported as "Giles Land," causing further confusion. Hence, Nordenskiöld was not the only one to mistake Kong Karls Land for Giles Land during these decades. For example, Norwegian ice pilot Erik Eriksen did just that in 
1853-a fact that later made Leigh Smith look for Giles Land in the area during his 1873 expedition (Capelotti 2013). Perhaps the most extreme interpretation of the Giles Land situation at this time was Baur's (1870), which placed a huge land mass, almost as large as Svalbard itself, east of Svalbard on his world map (Fig. 5). The land mass was labelled "Gillis Ld?," where the question mark must have been added to imply uncertainty regarding the position and/or expanse of the land.

Julius von Payer was a major early Arctic explorer, and considered the official discoverer of Franz Josef Land even though sealers had been there earlier. In his book concerning an Austro-Hungarian expedition to Novaya Zemlya, von Payer (1876) explicitly noted that he thought Giles Land was not a continent, but probably consisted of only one or more islands. On the route map from the expedition (Fig. 6), Giles Land is located at approximately its original position. While von Payer could not have sighted Giles Land because he was blocked by ice during his journey and never went north of $79^{\circ} \mathrm{N}$ in the seas between Svalbard and Franz Josef Land, it is nevertheless noteworthy that von Payer evidently saw no need to choose between Giles' original claim and Nordenskiöld's claim concerning the location of Giles Land. However, he could definitively dismiss the Baur (1870) theory of a huge land mass.

The German cartographer August Heinrich Petermann produced several Arctic maps, mostly published in his own geographical journal Petermanns Geographische Mitteilungen during the 1860s and 1870s. Petermann (1872) also provides a relatively detailed discussion of Giles Land according to his interpretation of the accumulated knowledge at the time. He observed correctly that Giles Land had become a kind of legend because so much time had passed since it was discovered in 1707 and that it had not yet been explored, let alone reached again. He noted that, where any attention at all was paid to

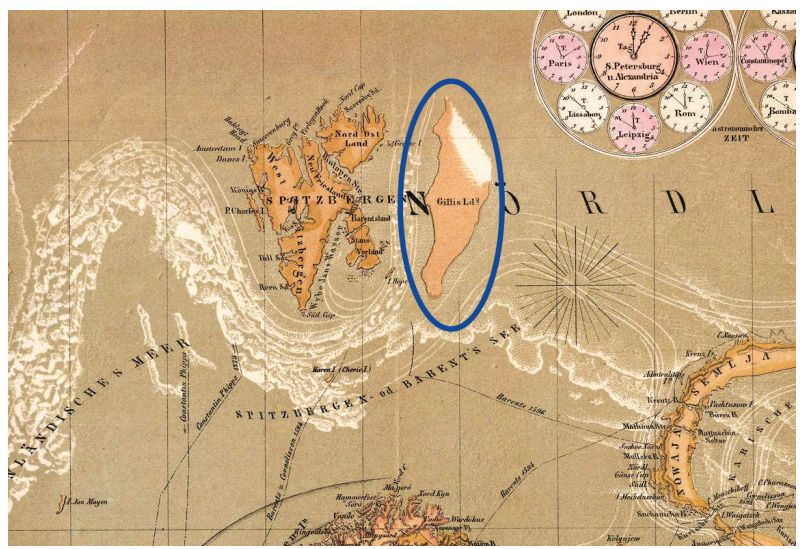

Fig. 5 Detail of Baur's map (1870) with "Gillis Ld?" circled.
Giles Land on the older maps, it was consistently placed approximately 50 nautical miles east of Nordaustlandet between $80^{\circ} \mathrm{N}$ and $80^{\circ} 10^{\prime} \mathrm{N}$. This was where Giles had originally claimed to have seen it, and there had been no debate on the matter until Nordenskiöld published his claim that he had seen Giles Land at $78^{\circ} 50^{\prime} \mathrm{N}$ from the top of Kvitberget in 1864 (what Nordenskiöld actually saw was Svenskøya, as mentioned above). In response to Nordenskiöld's claim, Petermann (1872: 112) noted acerbically that the Swedes, "unconcerned about the difference of about 75 miles, they call it Giles Land, as if someone would mistake the Rigi for Monte Salvatore near Lugano or Mont Blanc with St Gotthard," had no reason to believe that what they saw was Giles Land, especially as various Norwegians had already seen this land area located at $78^{\circ} 50^{\prime} \mathrm{N}$. Petermann finished his cutting criticism of Nordenskiöld with an assertion that the most credible information on the location of Giles Land placed it at $81^{\circ} 30^{\prime} \mathrm{N} 36^{\circ} \mathrm{E}$, far further north of where Giles had placed it. However, Petermann provided no persuasive evidence for this conclusion in his article. In fact, he explicitly stated that it was a conjecture derived from an extrapolation of an alleged sighting north of Svalbard by William Baffin 250 years earlier and some remote observations of wildlife in that direction. Despite such scanty evidence, Petermann (1872) attached a map (Fig. 7) where he placed Giles Land far to the north and somewhat east from its position on van Keulen's map. In addition, von Payer's (1876) imagined land to the north of the actual northernmost point of Franz Josef Land, appropriately named "Petermann Land" (Fig. 8), was almost certainly inspired by Petermann's idea of a Giles Land in the far north (Capelotti 2013).

Petermann's conjecture concerning a much more northerly position of Giles Land became widely accepted by cartographers within just a few years (e.g., Poppey 1875 (1874); Collin 1877 [1876]). Hence, there

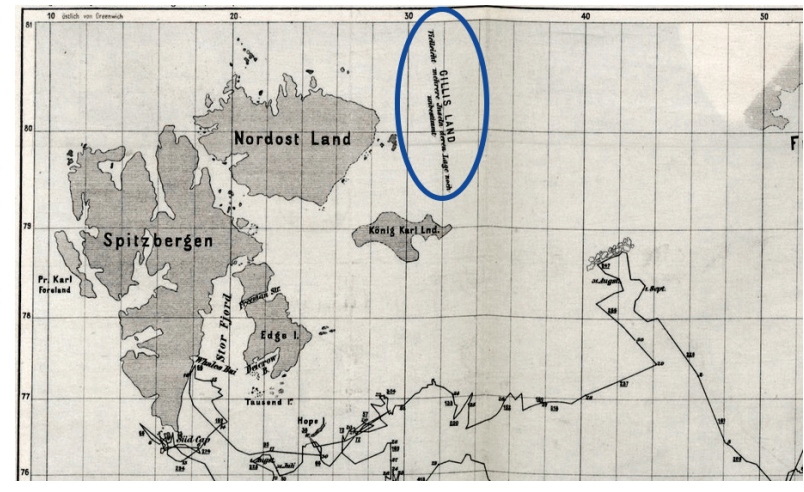

Fig. 6 Detail of Von Payer's map (1876) with the location of "Gillis Land" circled. 


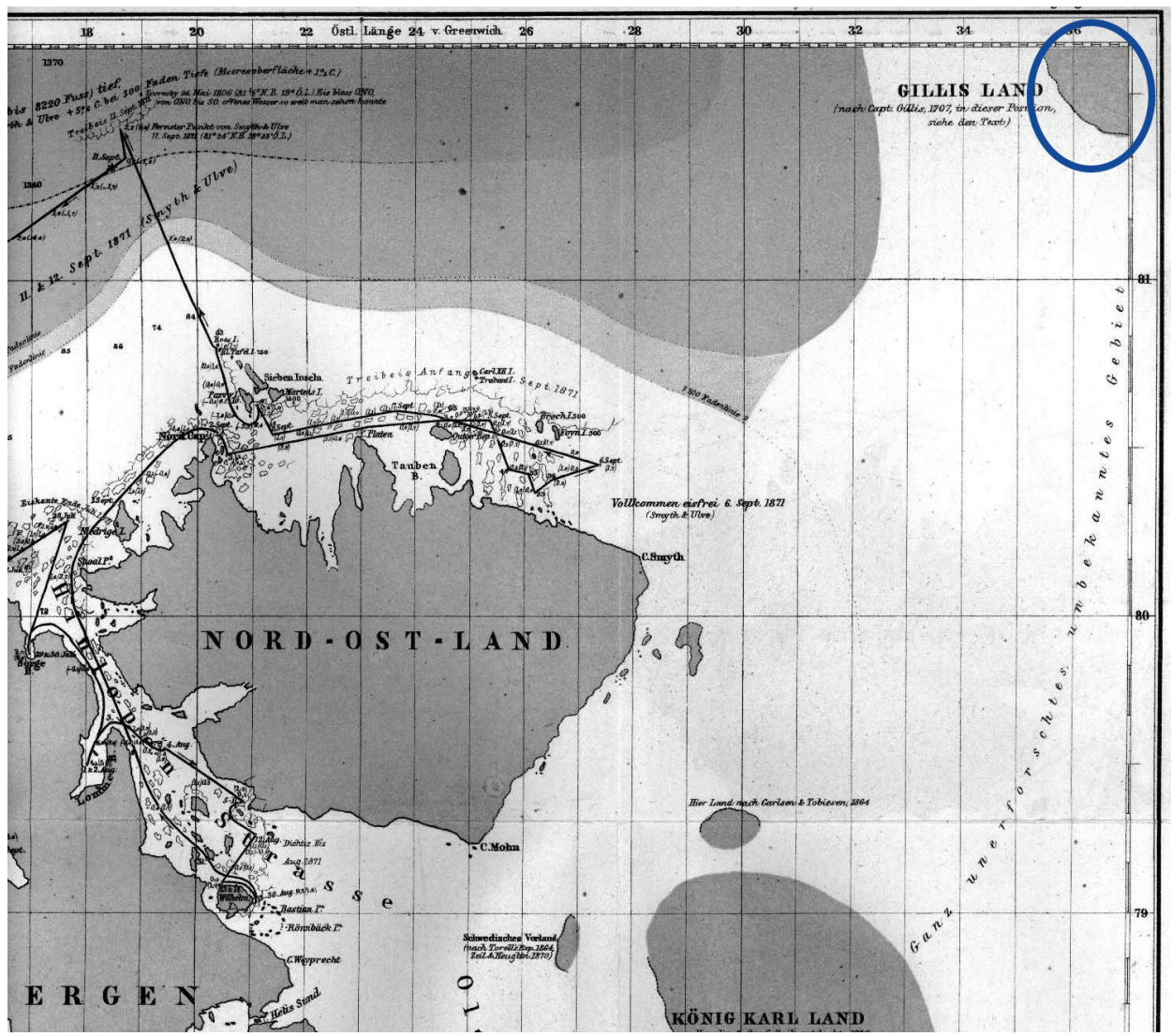

Fig. 7 Detail of Petermann's map (1872) with "Gillis Land" circled.

were few at the time who understood the significance of the discovery, by Norwegian Arctic skipper Kjeldsen from Tromsø, of an island at $80^{\circ} 09^{\prime} \mathrm{N} 32^{\circ} 35^{\prime} \mathrm{E}$ during a walrus-hunting expedition in 1876. Given the island was very unlikely to have been sighted since Giles originally discovered it in 1707 (Mills 2003), its relation to the illusive Giles Land remained unresolved. Cartographers began to introduce Kjeldsen's discovery of Kvitøya onto their maps, but often retained a belief in a mysterious Giles Land further north at approximately $81^{\circ} 30^{\prime} \mathrm{N}$, as Petermann (1872) had suggested. For example, Pettersen (1884), in his yearly review of current events in the Arctic seas as published in the Swedish anthropological and geographical journal Ymer, attached a map to his paper (Fig. 8) of the area that had been published by the Swedish Armed Forces Headquarters. On this map, Kvitøya is marked as "Förm. Land" ("Assumed land") at its actual position, but there is also a "Gillis Land" further to the north on the map. Another example is A.G. Nathorst (1896) who, in his article on F. Nansen's return from the Fram expedition, included a map showing the routes taken by Nansen in the Fram. While Kvitøya was entirely omitted from the

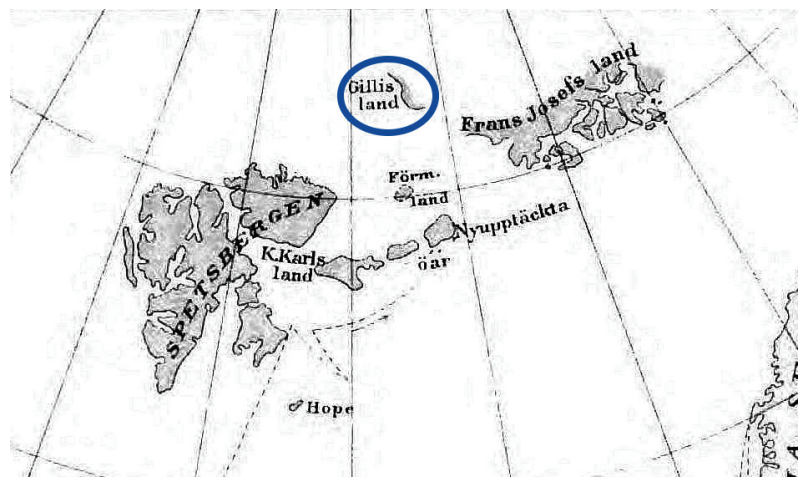

Fig. 8 Detail of Pettersen's map (1884) with "Gillis land" circled.

map without explanation, an unnamed south-westerly coastline was positioned to the north at approximately $81^{\circ} 30^{\prime} \mathrm{N}$.

An English map of the North Polar regions, alleged to be "compiled from the latest sources, including Dr Nansen's data," which Andrée brought with him on his balloon journey (Bartholomew 1897), also located a "Gillis Land" further north from Kvitøya, at approximately 
$81^{\circ} 30^{\prime} \mathrm{N}$ (Fig. 9). Thus, it is not surprising that Andrée looked out for it when he passed through the area, drifting on an ice floe. Nor is it surprising that he could not see it because there never was land there.

A serious search for the mysterious Giles Land was made by Frederick Jackson in August 1897, during the final weeks of the Jackson-Harmsworth 1894-1897 expedition to Franz Josef Land (Jackson 1899). On 8 August, he had been able to steam about 50 nautical miles to the north-west from Cape Mary Harmsworth on his ship Windward before meeting thick ice that forced him to turn back. Because Cape Mary Harmsworth is located at $80^{\circ} 35^{\prime} \mathrm{N} 44^{\circ} 54^{\prime} \mathrm{E}$, it is clear that Jackson managed to come relatively close to the position of Petermann's conjectured Giles Land. Jackson himself claimed (Jackson 1898) that he passed within 10 miles of the supposed coast of Giles Land. However, there was no land in sight. Furthermore, there was no indication of land in the vicinity because a sounding gave a reading of over 220 fathoms and indicated a bed of brown mud. Jackson wrote that he believed his observations established the non-existence of Giles Land. (It is interesting to note that Jackson, at his "farthest northwest" position in the Windward, on 8 August 1897, was relatively close to the position where the members of the Andrée expedition were located on that same day on the ice. The distance between the expeditions at that point was probably around $50 \mathrm{~km}$. Of course, neither party knew that.)

In maps published in the early 20th century, the assumed location of a Giles Land at $81^{\circ} 30^{\prime}$ became less frequently depicted, but some geographers and cartographers still believed this locational information was accurate. For example, it was still indicated at $81^{\circ} 30^{\prime}$ on the 1907 edition of a German map covering the eastern part of the Barents Sea, published by the German Marine Office 1907, and brought on Gunnar Isachsen's Norwegian expedition to Spitsbergen 1909-1910 (Reichs-Marine-Amt 1907). It was also retained after a large correction in 1908 of the British chart covering the Barents and Greenland seas, published by the British Hydrographic Department of the Admiralty (Powell 1909; Fig. 10). However, nobody had yet managed to arrive at these precise coordinates to confirm whether Giles Land existed and return alive.

Because Andrée's last camp on Kvitøya, along with his diaries, was not found until 1930, the Giles Land confusion and mystery continued. For example, during the 1925 exploration season, Frank Worsley (probably best known as the captain of Shackleton's ship Endurance during the Antarctic expedition of 1914-1917) made two serious attempts to reach Giles Land in his ship Island (Worsley 2003). It should be noted that Worsley and others at that time explicitly distinguished "Gillis Land"

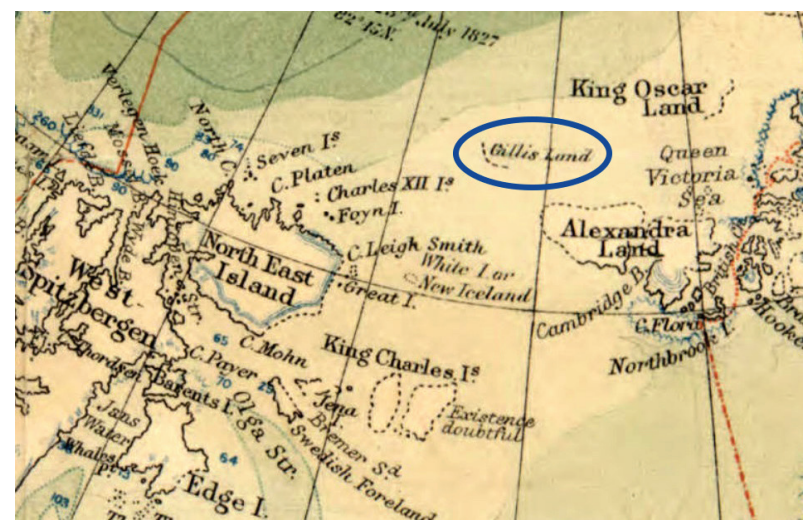

Fig. 9 Detail of Bartholomew's map (1897) with "Gillis Land" circled.

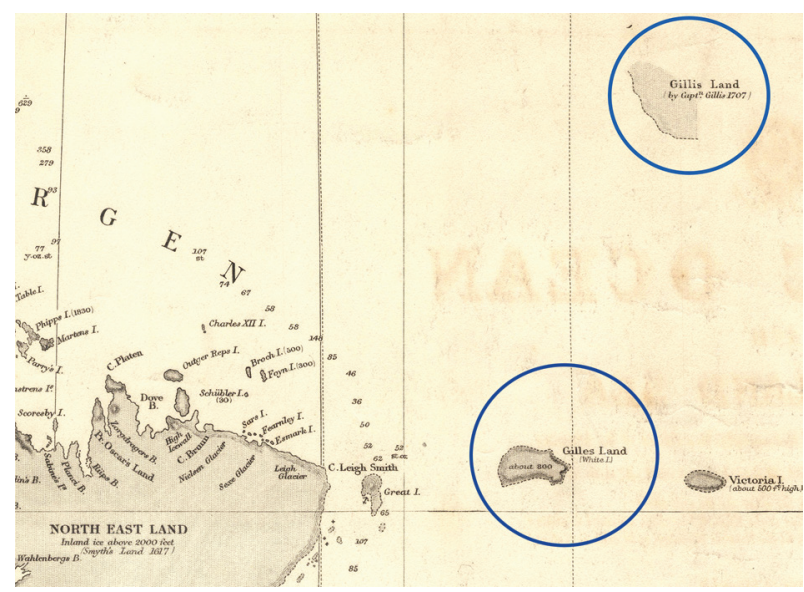

Fig. 10 Detail of Powell's map (1909) with "Gillis Land" and "Gilles Land" circled.

(at $81^{\circ} 30^{\prime} \mathrm{N}$ ) from “Gilles Land" (Kvitøya, at $80^{\circ} 09^{\prime} \mathrm{N}$ ), in line with Powell (1909) above, although both names are obviously derived from "Giles Land". One should also note that the search for "Gillis Land" was one component comprising the objectives of Worsley's expedition (see Worsley 2003:6). In other words, there were still experienced and accomplished polar explorers who believed in the myth of a Giles Land.

During Worsley's first attempt to reach $81^{\circ} 30^{\prime} \mathrm{N}$, towards the end of July, he managed to reach $80^{\circ} 52^{\prime} \mathrm{N}$, at which point the ship's propeller became useless after becoming seriously damaged by pack ice. This disaster, in combination with the ice being practically impenetrable, forced him to turn back. At his second attempt, under sail in mid-September, the pack ice stopped him some 60 miles distance from his objective. This time, however, the crew observed "a strong appearance of land against the glow of approaching sunrise" (Worsley 2003: 118) in a north-north-east direction. They saw it for several 
hours at dawn, and again later the same day at midnight and through the night. Despite being a full degree of latitude away, and although the appearance of land was too far to the west given its expected position on the charts, Worsley was almost certain that he could see the illusive Giles Land. It appears more likely that what he saw was probably some kind of sea ice deformation or an iceberg, in combination with wishful thinking.

Perhaps the last expedition to make a serious attempt to reach the mythical Giles Land at $81^{\circ} 30^{\prime} \mathrm{N}$ was the Soviet Sadko expedition in 1935, involving a ship equipped with aircraft (Barr 1977). Like Worsley in 1925, the expedition leader G.A. Ushakov was of the opinion that "Gilles Island" (Kvitøya) should not be confused with "Gillis Land" further north. However, they found no land in the vicinity of $81^{\circ} 30^{\prime} \mathrm{N}$ despite good visibility from the air. In combination with the fact that the Soviet ice-breaker Krasin had specifically searched for Giles Land a few years before and its captain, Karl Eggi, found no land in sight at $81^{\circ} 40^{\prime} \mathrm{N} 36^{\circ} \mathrm{E}$ with over $32 \mathrm{~km}$ visibility and a depth of $200 \mathrm{~m}$ (Samoylovich 1934), the myth concerning the existence of a Giles Land could finally be discarded.

\section{Discussion}

After Giles' initial discovery in 1707, the real Giles Land, namely, Kvitøya, was probably not sighted again until 1876, when Kjeldsen rediscovered it (Andrée et al. 1931). The reason for this long delay is simple. Historically, Kvitøya had been very hard to reach because of the pack ice that used to enclose it, even in the summer. While the Gulf Stream certainly helped to keep the water west of Svalbard open, this was not the case to the east. Nowadays, climate change has moved the average position of the ice edge farther north, but thick ice remains a challenge for ships in the area. It would seem that the 1876 season was relatively ice-free in the area because Kjeldsen was able to reach Kvitøya.

During the 19th century, Norwegian walrus-hunters continually asserted that there was land east of Svalbard and began referring to this land area as Giles Land (Leslie 1879), even though the land in question was further south than where Giles had seen his land area in 1707. This was most likely to have been the principal reason why Nordenskiöld chose to call the land area he saw to the east of Kvitberget in 1864 "Giles Land," claiming he did not want to encumber his map with new names.

The fact that the early maps of the area included a named place, which was practically impossible to reach, must have helped Giles Land develop a certain mysteriousness. Based on nothing more than Petermann's conjecture in 1872, a fruitless search for Giles Land in the far north continued well into the 1930s until the conclusion was reached that it did not exist. It is well known that Petermann often based conclusions relating to his maps on his own theoretical deductions, involving hypotheses that were difficult to reject in practice even when there were empirical observations that falsified them (Tammiksaar et al. 1999). The Giles Land enigma is a good example of what can happen when using this approach. Petermann had previously positioned Giles Land in varying positions on his maps, so it is clear he engaged in some degree of speculative assessment from time to time. However, in Petermann's defence, it is worth mentioning that his unorthodox methods also increased the general interest for polar research at the time.

It should be emphasized that not everybody in the polar exploration community believed in Petermann's idea of a Giles Land at $81^{\circ} 30^{\prime} N$. For example, Nordenskiöld, quoted by Leslie (1879: 256), stated: "In various maps published during the last few years Petermann has marked with the name Giles' Land, a land far to the northeast of the northeastern point of North East Land, situated as far to the north of van Keulen's Giles' Land as King Carl's Land is situated to the south of it. It is reserved for futurity to show whether this land does in fact exist." Clements Markham was even more direct concerning the topic in his book on Baffin's voyages (Markham 1881), in which he stated that Petermann had "misinterpreted a loose, second-hand statement" by Barrington (1818) regarding Baffin's 1614 sightings in the seas north of Svalbard and that there was "not the slightest foundation for Dr. Petermann's theory." (Markham most likely referred to the passage "In the year 1614 , Baffin proceeded to $81^{\circ}$, and thought he saw land as far as $82^{\circ}$ to the Northeast of Spitzbergen" [Barrington 1818: 41].) Nevertheless, it took another 50 years to dismiss the myth conclusively and reach a consensus that Petermann's hypothesis was wrong.

Finally, it should be mentioned that Giles Land is not the only case of cartographic confusion in the history of Arctic exploration. There are other examples of substantial changes of prior viewpoints regarding geographical features in the North. For example, English whaler William Scoresby was able to reduce the longitudinal extent of eastern Greenland substantially during his 1822 expedition, compared to the prior maps, and found that the eastern coast direction was almost due south instead of south-west between the 69th and 75 th parallels (Greely 1895).

\section{Conclusion}

When Andrée searched in vain for Giles Land in August 1897 during his march over the ice, he was very likely 
more sceptical about its existence than what his short diary notes from those days reveal. Andrée was highly intelligent and preferred to rely on solid scientific reasoning. Hence, assuming he had read Petermann's article from 1872 in preparation for his own exploration, he would probably have questioned the essentially groundless idea of a Giles Land situated far more to the north than anyone had ever been at that meridian. In hindsight, it seems extraordinary that this idea became so widespread, but one reason might have been that people simply took Petermann's map at face value, without consideration of his written arguments. However, not everyone was convinced, and alternative more informed views were expressed. For example, Nathorst (1897: 101) wrote: "The true 'Gilies Land' has, during the last twenty years, been seen at least twice from the vicinity of the north-eastern point of North-East Land," specifying the sighting by Kjeldsen in 1876 and one made in 1883 by Captain Sörensen of Tromsø from the islands of Repøyane. Given that Nathorst and Andrée were both members of the editorial board of the Swedish journal Ymer in the 1890s, it seems probable that they had at least discussed the Giles Land issue. Hence, Andrée would most likely have been surprised if he had actually encountered land there at $81^{\circ} 30^{\prime} \mathrm{N}$ in August 1897.

To conclude, it seems clear that Giles Land would never have become such an enduring enigma if the influential Petermann had not erroneously moved it to $81^{\circ} 30^{\prime} \mathrm{N}$ on his map from 1872 . Without that misguided authoritative intervention, Kjeldsen's sighting of Kvitøya in 1876 would then have been much easier to connect to Giles' original discovery in 1707.

\section{Acknowledgements}

The author wishes to thank two anonymous reviewers for their helpful and constructive comments on an earlier version of this article.

\section{Disclosure statement}

The author reports no conflict of interest.

\section{References}

Andrée S.A., Strindberg N. \& Frænkel K. 1931. The Andrée diaries. London: John Lane the Bodley Head.

Barr W. 1977. The first Soviet high-latitude expedition. Arctic 30, 205-216, https://doi.org/10.14430/arctic2701.

Barrington D. 1818. The possibility of approaching the North Pole asserted. New York: James Eastburn \& Co.

Bartholomew J.G. 1897. Physical chart of North Polar regions. Unpaginated map in F. Nansen: Farthest north. Vol. 1. New York: Harper and Brothers.
Baur C.F. 1870. Neueste Karte der Erde. Mit Rücksicht auf das Bedürfniss des Handelstandes. (Latest map of the Earth. With regard to the needs of trade.) Stuttgart: Verlag von Julius Mayer.

Bellin J.N. 1780 (1758). Carte du Spits-Berg suivant les Hollandois. (Map of Spitsbergen based on the Dutch.) Unpaginated map in J.-F. de La Harpe (1780): Abrégé de l'histoire générale des voyages. (Summary of the general history of travels.) Paris: Ménard et Desenne.

Brice A.M. 1896. The Jackson-Harmsworth Polar expedition. The Geographical Journal 8, 543-564, https://doi. org/10.2307/1774217.

Capelotti P.J. 2013. Shipwreck at Cape Flora. Calgary, AB: University of Calgary Press.

Collin C.E. 1877 (1876). Région arctique. (Arctic region.) Unpaginated map in L.V. de Saint Martin (1877): Atlas universel. (Universal Atlas.) Paris: Hachette.

Conway M. 1906. No man's land: A history of Spitsbergen from its discovery in 1596 to the beginning of the scientific exploration of the country. Cambridge: Cambridge University Press.

Doncker H. 1663. De zee-atlas ofte water-waereld. (The sea atlas or the water world.) Amsterdam: Henrick Doncker.

Dunér N. \& Nordenskiöld A.E. 1865. Anteckningar till Spetsbergens geografi. (Notes on Spitsbergen geography.) Kungliga Svenska Vetenskapsakademiens Handlingar 6(5). Stockholm: Royal Swedish Academy of Sciences.

Dunér N., Malmgren A.J. \& Nordenskiöld A.E. 1867. Svenska expeditioner till Spetsbergen och Jan Mayen åren 1863-64. (Swedish expeditions to Spitsbergen and Jan Mayen in 1863-64.) Stockholm: P.A. Norstedt \& Söner.

Greely A.W. 1895. Handbook of Arctic discoveries. Boston: Roberts Brothers.

Jackson F.G. 1898. Three years' exploration in Franz Josef Land. The Geographical Journal 11(2), 113-138, https://doi. org/10.2307/1774430.

Jackson F.G. 1899. A thousand days in the Arctic. London: Harper \& Brothers.

Lantz B. 2018. Could the members of the 1897 Andrée balloon expedition have survived? Polar Record 54, 234-236, https://doi.org/10.1017/S0032247418000402.

Le Rouge G.-L. 1758. Atlas nouveau portatif a l'usage des militaires, collèges et $d u$ voyageur. (New portable atlas for military, college and traveler use.) Paris: Le Rouge $\&$ Prault Fils.

Leslie A. 1879. The Arctic voyages of Adolf Erik Nordenskiöld. London: MacMillan and Co.

Markham C.R. 1881. The voyages of William Baffin, 1612-1622. London: The Hakluyt Society.

Mills W.J. 2003. Exploring polar frontiers: a historical encyclopedia. Santa Barbara: ABC-CLIO Ltd.

Nansen F. 1897. Farthest north. New York: Harper and Brothers.

Nathorst A.G. 1896. Nansens och "Frams" återkomst. (The return of Nansen and the Fram) Ymer 16, 193-202.

Nathorst A.G. 1897. Gilies Land. The Geographical Journal 9(1), 101, https://doi.org/10.2307/1773656.

Petermann A.H. 1872. Gillis-Land, König Karl-Land und das Seeboden-Relief um Spitzbergen, nach dem Standpunkte der Kenntniss im Jahre 1872. (Giles Land, Kong Karls Land and the seabeds around Spitsbergen according to the 
knowledge in 1872.) Petermanns Geographische Mitteilungen 18, $111-112$.

Pettersen K. 1884. Det europæiske Polarhav i Sommeren 1884. (The European Polar Sea during the summer of 1884.) Ymer 4, 223-232.

Phipps C.J. 1774. A voyage towards the North Pole. London: J. Nourse.

Poppey C. 1875 (1874). Polar-Karte enthaltend. (Polar map.) Unpaginated map in A. Stieler (1875): Handatlas. (Hand atlas.) 6th edn. Gotha: Justus Perthes.

Powell E.J. 1909. Arctic Ocean and Greenland Sea. From the latest information in the Hydrographic Department of the Admiralty. Large corrections September 1908. London: Davies, Bryer \& Co.

Reichs-Marine-Amt 1907. Nördliches Eismeer, Barents see. (Northern Arctic Ocean, Barents Sea.) Nr. 155 (Tit. XIII Nr.31), Maßstab 1:2 000 000. Leipzig and Berlin: Gieseke $\delta$ Devrient.

Samoylovich R.L. 1934. Vo l'dakh Arktiki: pokhod "Krasina" letom 1928 goda. (My Journey in the Arctic with Krasin during the summer of 1928.) Leningrad: Izdanie Vsesoyuznogo Arkticheskogo Instituta.
Tammiksaar E., Sukhova N.G. \& Stone I.R. 1999. Hypothesis versus fact: August Petermann and polar research. Arctic 52, 237-244, https://doi.org/10.14430/arctic929.

van Keulen G. 1969-1970 (ca. 1714). Nieuwe afteekening van Het Eyland Spits-Bergen. (New map of the island of Spitsbergen.) Unpaginated map in J. van Keulen \& G. van Keulen. (1969-70): De Nieuwe Groote Ligtende Zee-Fakkel, Amsterdam 1716-1753. (The new great shining sea torch, Amsterdam, 1716-1753.) Amsterdam: Theatrum Orbis Terrarum.

von Payer J. 1876. Die Österreichisch-ungarische Nordpol-Expedition in den Jahren 1872-1874. (The Austro-Hungarian North Pole Expedition in 1872-74.) Vienna: A. Hoelder.

Worsley F.A. 2003. Under sail in the frozen north. Santa Barbara: The Narrative Press.

Wråkberg U. 2015. Chapter 8. The politics of place names: a summation. In P.J. Capelotti (ed.): Proceedings of a Workshop on the Historic Place names of Franz Josef Land. Septentrio Conference Series 2015 (3). Pp. 69-89. Tromsø: Septentrio Conference and University Park, PA: The Polar Center, http:// dx.doi.org/10.7557/5.3585. 